Original article

\title{
Molecular characterization and population structure of the honeybees from the Balearic islands (Spain)
}

\author{
Pilar DE LA RÚA ${ }^{\mathrm{a} *}$, José GALIÁN ${ }^{\mathrm{a}}$, José SERRANO ${ }^{\mathrm{a}}$, \\ R.F.A. MORITZ \\ ${ }^{a}$ Dpto. Biología Animal, Facultad de Veterinaria, Apdo. 4021, Universidad de Murcia, \\ 30071 Murcia, Spain \\ b Institute of Zoology, Martin-Luther-University Halle-Wittenberg, Kroellwitzer Str. 44, \\ 06099 Halle/Saale, Germany
}

(Received 3 November 2000; revised 20 May 2001; accepted 28 May 2001)

\begin{abstract}
Honeybees (Apis mellifera L.) were collected from 23 localities on the Balearic islands in the Mediterranean Sea. The mitochondrial genome (mtDNA) was surveyed for diagnostic restriction sites and characterized with DraI digestion of the tRNA ${ }^{\text {leu}}-\mathrm{COII}$ intergenic region. Both approaches demonstrated that honeybees bearing either African or west European haplotypes coexist on the Balearic islands. Two African and two west European haplotypes were found with different frequencies and distribution among the islands. Phylogenetic and population structure analyses support the clustering of these islands in two groups: Majorca-Minorca (Gymnesic) and Ibiza-Formentera (Pityusic) what corroborates the current biogeographical division of the Balearic organisms. These results partially agree with the observed distribution of African haplotypes in honeybee populations from other Mediterranean islands. The present distribution of genetic markers may reflect also the influence of human movements, trade and settlements from prehistoric times.
\end{abstract}

Apis mellifera / Balearic islands / mtDNA / biogeography

\section{INTRODUCTION}

European subspecies of Apis mellifera L. were first classified by morphometric studies (Ruttner, 1988). They fall into four distinct branches $\mathrm{A}, \mathrm{M}, \mathrm{C}$ and $\mathrm{O}$, that can be traced around the Mediterranean into the
Middle East. In the last decade, molecular analyses supplemented morphometrical data in studies about the biogeography and description of the subspecies complex of the honeybee Apis mellifera. The phylogenetic relationships based on molecular data (Cornuet and Garnery, 1991; Garnery

* Correspondence and reprints

E-mail: pdelarua @um.es 
et al., 1992; Estoup et al., 1995; Arias and Sheppard, 1996) agree in many aspects with those previously obtained with morphological and behavioral data (Ruttner, 1988). These studies have shown that the west European subspecies A. m. mellifera and some northern Iberian populations of $A$. $m$. iberica correspond to the M lineage, the subspecies distributed from eastern Europe to Italy as A. m. caucasica, A. m. carnica, and $A$. $m$. ligustica among others, form the lineage $\mathrm{C}$, and the $\mathrm{A}$ lineage encompasses all the African subspecies and also those populations located in southern Iberia and Mediterranean islands as Sicily (A. m. sicula, Garnery et al., 1993) and Malta (A. m. ruttneri, Sheppard et al., 1997). The existence of the fourth evolutionary lineage $(\mathrm{O})$, comprising mellifera subspecies from the Middle East area has been recently confirmed using mitochondrial and microsatellite variability (Franck et al., 2000b; Palmer et al., 2000).

The honeybees of the Iberian Peninsula have been of particular interest because of the hypothesized status of $A$. $m$. iberica as a hybrid between European A. m. mellifera and African A. m. intermissa. In agreement with this hypothesis, a decreasing gradient of African mitochondrial haplotypes occurs from south to north, while the inverse situation occurs with west European haplotypes (Smith et al., 1991; Garnery et al., 1995, 1998a; Sheppard et al., 1996). On the contrary, microsatellite analyses of $A$. $m$. iberica show allelic patterns similar to $A$. $m$. mellifera, with almost no introgression of African alleles (Franck et al., 1998; Garnery et al., 1998b).

Some Mediterranean islands harbor endemic honeybee populations as $A$. $m$. sicula in Sicily and A. m. ruttneri in Malta. These populations have been studied using morphometric (Sheppard et al., 1997; Ruttner, 1988) and molecular approaches (Garnery et al., 1993; Sheppard et al., 1997; Franck et al., 2000a). Mitochondrial haplotypes found in these honeybees have an
African origin and similar haplotypes have been observed at high frequencies in the Iberian honeybee. Initial results on some Greek islands also show this pattern (Garnery et al., 1993). The Mediterranean distribution of African haplotypes could be interpreted in the light of successive colonization and bottlenecks events occurred in Europe in the Pleistocene period. Patterns further complicated by human influence during historic times. In Corsica and Sardinia, honeybee populations display a high mitochondrial differentiation with European haplotypes from the lineages $\mathrm{M}$ and $\mathrm{C}$, clearly due to a human influence (Franck et al., 2000a).

Populations on the Balearic islands are situated in the western Mediterranean Sea close to the eastern Iberian coast. The three northern islands (Majorca, Minorca and Cabrera) make up the Gymnesic archipelago, whereas Ibiza and Formentera to the south form the Pityusic group. According to a model of colonization of the Balearics due to natural factors, we hypothesized that there may be differences between honey bee populations from the Gymnesic and the Pityusic island groups, as is known for other organisms (Colom, 1964; Compte, 1968; Cuerda, 1975; Palmer et al., 1999, etc.). Such differences reflect the separate history of both archipelagos in terms of colonization over the last two million years, including the time when Apis mellifera probably expanded its range westwards from the East Mediterranean region (Ruttner, 1988).

Variation in the mitochondrial molecule allows discrimination among the evolutionary lineages of honeybee subspecies. Several approaches have been described for studying the sequence variability of different mitochondrial regions (reviewed for Africanized bees in Sheppard and Smith, 2000). Some of the molecular studies rely on the length and restriction site polymorphisms of the mitochondrial genome (Crozier et al., 1991; Hall and Smith, 1991). Garnery et al. (1993) used the length polymorphism of the 
intergenic tRNA ${ }^{\text {leu_COII region, combined }}$ with a restriction site polymorphism in the same region, to design a simple and stringent test that designates honeybees bearing different haplotypes to membership in one of the four mtDNA lineages of subspecies. This intergenic region is basically composed of two sequences called $\mathrm{P}$ and $\mathrm{Q}$. The type of $\mathrm{P}$ sequence ( $\mathrm{P}$ with 54-56 bp, $\mathrm{P}_{0}$ with 62-69 bp and $\mathrm{P}_{1}$ with $50 \mathrm{bp}$ ) combined with the number of $\mathrm{Q}$ sequences characterise the four evolutionary lineages.

In this study we analyzed the mtDNA (restriction site and length polymorphisms) of 110 colonies from the Balearic islands to characterize the Balearic honeybee populations and to test current hypotheses about their origin and evolution.

\section{MATERIALS AND METHODS}

\subsection{Sampling and DNA extraction}

A total of 110 colonies were sampled from 23 different localities distributed on Majorca, Minorca, Ibiza and Formentera during August 1999 and February 2000 (Fig. 1 and Tab. I). At least 30 worker bees were collected from each colony. The hives were opened and the bees were trapped from the inner frames to prevent the collection of drifting bees. Bees were immediately killed by immersion in absolute ethanol and kept at $-20{ }^{\circ} \mathrm{C}$ until they were processed in the laboratory.

Total DNA was extracted from one worker thorax per colony $(\mathrm{N}=110 \mathrm{sam}-$ ples) after rinsing the bees for one hour following Garnery et al. (1993). DNA isolation was performed following the Chelex method (Walsh et al., 1991).

\subsection{PCR amplification and DNA digestions}

The target regions containing the diagnostic restriction sites were amplified and digested following Smith et al. (1997) (Tab. II). Three diagnostic restriction sites were analyzed: $B g l I I$ in the cytochrome b gene (Crozier et al., 1991), and HincII and $X b a \mathrm{I}$ in the subunit I of the cytochrome oxidase gene (COI) (Hall and Smith, 1991).

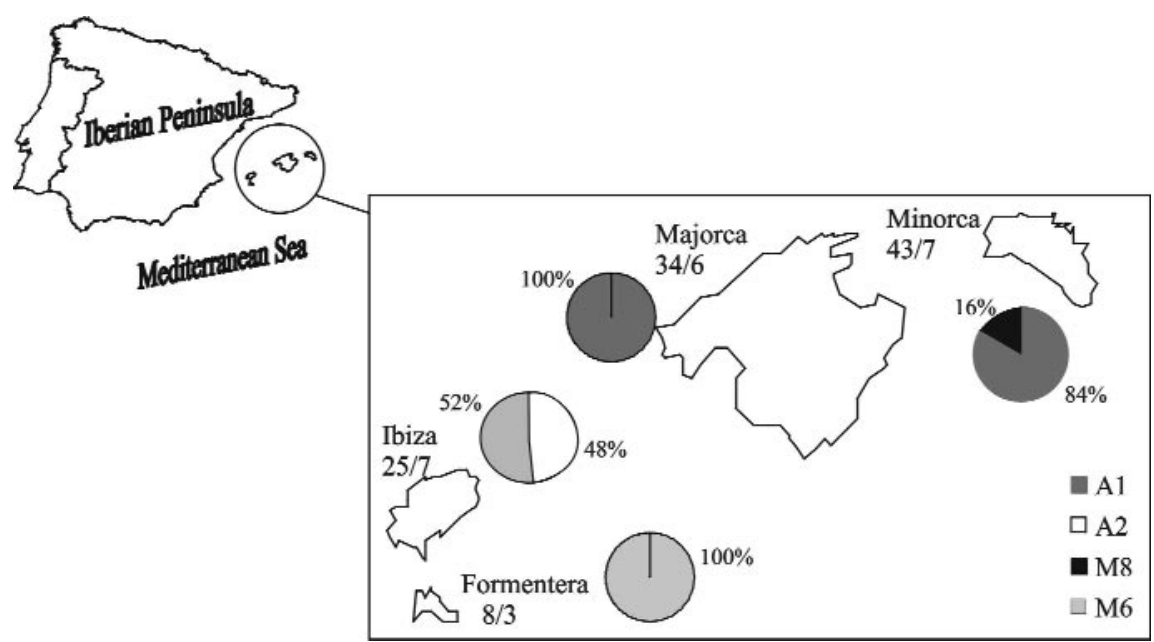

Figure 1. Map of the sampled localities from Majorca, Minorca, Ibiza and Formentera showing the number of colonies and localities sampled (values before and after the dash) and haplotype distribution and frequencies. 
PCR amplification of the intergenic


lowing Garnery et al. (1992) with the primers E2 located at the 5'-end of the
tRNA $^{\text {leu }}$ gene and $\mathrm{H} 2$ located at the 5'-end of the COII gene. The four amplified resulting products were visualized after the electrophoretic separation on $1.5 \%$ agarose gels,

Table I. Distribution of the studied Apis mellifera populations from the Balearic islands and frequency (percent) of the haplotypes revealed by Dra I restriction.

\begin{tabular}{|c|c|c|c|c|c|c|}
\hline \multirow[t]{2}{*}{ Island } & \multirow[t]{2}{*}{ Locality } & \multirow{2}{*}{$\begin{array}{l}\text { No. of } \\
\text { colonies }\end{array}$} & \multicolumn{4}{|c|}{ Haplotypes } \\
\hline & & & A1 & A2 & M8 & M6 \\
\hline Majorca & $\begin{array}{l}\text { Can Arabí } \\
\text { Binissalem } \\
\text { Ariany } \\
\text { Petra } \\
\text { Castellitx } \\
\text { Campos }\end{array}$ & $\begin{array}{l}4 \\
6 \\
4 \\
6 \\
6 \\
8\end{array}$ & $\begin{array}{l}100 \\
100 \\
100 \\
100 \\
100 \\
100\end{array}$ & & & \\
\hline Minorca & $\begin{array}{l}\text { San Climent } \\
\text { Alaior } \\
\text { Es Tudons } \\
\text { Cimentera } \\
\text { El Toro } \\
\text { Sierra Morena } \\
\text { Lliberto }\end{array}$ & $\begin{array}{r}6 \\
6 \\
11 \\
5 \\
5 \\
5 \\
5\end{array}$ & $\begin{array}{r}100 \\
100 \\
55 \\
60 \\
100 \\
100 \\
100\end{array}$ & & & $\begin{array}{l}45 \\
40\end{array}$ \\
\hline Ibiza & $\begin{array}{l}\text { S. Gertrudis } \\
\text { S. Eulalia } \\
\text { Jesús } \\
\text { S. Agustín } \\
\text { Cala Llonga } \\
\text { S. Miguel } \\
\text { S. Jordi }\end{array}$ & $\begin{array}{l}4 \\
4 \\
4 \\
4 \\
4 \\
4 \\
1\end{array}$ & & $\begin{array}{l}75 \\
75 \\
75 \\
\\
75\end{array}$ & $\begin{array}{r}25 \\
25 \\
25 \\
100 \\
25 \\
100 \\
100\end{array}$ & \\
\hline Formentera & $\begin{array}{l}\text { S. Francisco } 1 \\
\text { S. Francisco } 2 \\
\text { S. Fernando }\end{array}$ & $\begin{array}{l}2 \\
3 \\
3\end{array}$ & & & $\begin{array}{l}100 \\
100 \\
100\end{array}$ & \\
\hline
\end{tabular}

Table II. Presence (+) or absence (-) of three diagnostic restriction sites and haplotype distribution in the Apis mellifera populations from Majorca, Minorca, Ibiza and Formentera (cyt $b=$ cytochrome oxidase $b$, COI and COII = cytochrome oxidase I and II).

\begin{tabular}{|c|c|c|c|c|c|c|c|}
\hline \multicolumn{2}{|c|}{ Haplotypes } & \multicolumn{6}{|c|}{ Islands } \\
\hline $\begin{array}{l}\text { Amplified } \\
\text { region }\end{array}$ & $\begin{array}{c}\text { Restriction } \\
\text { enzyme }\end{array}$ & Majorca & Min & $\mathrm{rca}$ & Ibi & iza & Formentera \\
\hline Cyt b & $B g l \mathrm{II}$ & - & - & + & - & + & + \\
\hline COI & HincII & - & - & + & - & + & + \\
\hline COI & $X b a \mathrm{I}$ & - & - & - & - & - & - \\
\hline $\mathrm{tRNA}^{\text {leu_COII }}$ & $\operatorname{DraI}$ & $34 \mathrm{~A} 1$ & $36 \mathrm{~A} 1$ & $7 \mathrm{M} 8$ & $12 \mathrm{~A} 2$ & 13 M6 & $8 \mathrm{M} 6$ \\
\hline
\end{tabular}


stained with ethidium bromide, and photographed under ultraviolet illumination.

Ten $\mu \mathrm{L}$ aliquots of the resulting PCR products were digested with five units of each of the following enzymes $B g l \mathrm{II}$, HincII, $X b a \mathrm{I}$ and DraI. The restriction reactions were kept in a waterbath at $37{ }^{\circ} \mathrm{C}$ for $4-12 \mathrm{~h}$ and the resulting fragments were visualized in $1.5 \%$ agarose gels $(\mathrm{BglII}, \mathrm{HincII}$ and $\mathrm{XbaI}$ digestions) or $8 \%$ acrylamide gels (DraI digestion) and stained with ethidium bromide. Photographs were taken for documentation.

\subsection{Statistical analyses}

The Fischer exact test was performed to examine the differences in the distribution of haplotypes and evolutionary lineages among the islands with the program STRUC from the GENEPOP package version 3.1c (Raymond and Rousset, 1995). The AMOVA test for population structure was calculated using the ARLEQUIN program (Schneider et al., 1997).

\subsection{Phylogenetic analysis}

Results obtained in this work were combined with those from the region of Murcia located in the southeastern region of the Iberian Peninsula (de la Rúa et al., 1999). We used the maximum likelihood approach performed on the frequency of haplotypes present in each population. Bootstrap values (in \%) were obtained after 2000 iterations of the data set in every case (Hedges, 1992). Programs included in the package PHYLIP (version 3.5c, Felsenstein 1993) were used for these purposes.

\section{RESULTS}

\subsection{Mitochondrial DNA characterization}

As a first step in the molecular characterization of the honeybee populations of the Balearic islands, we performed restriction analyses after the amplification by PCR of the cytochrome b (cyt b) and the COI mitochondrial DNA regions. Results (Tabs. I and II) show that most colonies have the restriction pattern characteristic of the African evolutionary lineage i.e. the $B g l \mathrm{II}$ site in the cyt $\mathrm{b}$ region and HincII and $\mathrm{XbaI}$ sites in the COI were absent. In 28 out of 110 studied colonies the restriction pattern typical of the evolutionary lineage from Western Europe was found. We did not detect colonies belonging to other lineages.

The intergenic tRNA ${ }^{\text {leu }}$-COII region amplified by PCR yielded products with two sizes, either ca. 620 or ca. 815 base pairs. The restriction with the enzyme DraI revealed four different patterns: A1, A2, M6 and M8 (Fig. 2 and Tab. II). A1 and A2 contain the $\mathrm{P}_{0}$ sequence and differ in the presence of one (A1) or two (A2) copies of the $\mathrm{Q}$ sequence. Their restriction patterns and composition are characteristic of African

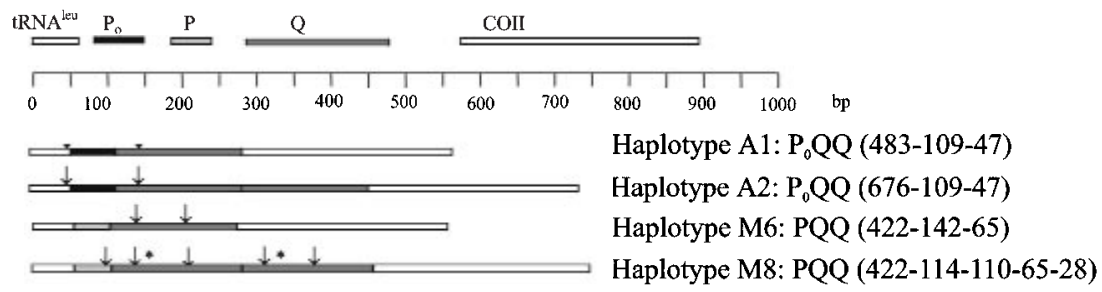

Figure 2. Restriction maps of the haplotypes found in the Balearic honeybee populations (following Garnery et al., 1993). Arrows indicate restriction sites and asterisks indicate two fragments with identical sizes. The size of the fragments after the DraI restriction is also shown. 
Table III. AMOVA design and results of the analysis of the population structure of Apis mellifera from the Balearic islands.

\begin{tabular}{lrrrrr}
\hline Source of variation & d. f. & & $\begin{array}{c}\text { Sum of } \\
\text { squares }\end{array}$ & $\begin{array}{c}\text { Variance } \\
\text { components }\end{array}$ & $\begin{array}{c}\text { Percentage } \\
\text { of variation }\end{array}$ \\
\cline { 1 - 3 } \cline { 3 - 5 } Among groups & 1 & 28.380 & 0.502 & 35.52 \\
Among islands within groups & 2 & 9.152 & 0.149 & 10.53 \\
Within islands & 107 & 81.639 & 0.763 & 53.95 \\
Total & 110 & 119.171 & 1.414 & \\
\hline
\end{tabular}

subspecies of $A$. mellifera, thus confirming that these colonies should be included in the African lineage. The haplotypes M6 and M8 display typical west European patterns containing the $\mathrm{P}$ sequence in its intergenic region, and one (M6) or two (M8) copies of the $\mathrm{Q}$ sequence.

\subsection{Genetic diversity and population structure}

The distribution and the relative frequencies of these four haplotypes in the sampled islands are given in Figure 1. The haplotype A1 occurred in high frequency on Majorca (100\%) and Minorca (84\%) and the haplotype A2 was only detected on Ibiza (42\%). Haplotypes corresponding to the M lineage have been observed on Minorca $(\mathrm{M} 8,16 \%)$ and at high frequency on Ibiza (M6, 52\%) and Formentera (M6, 100\%).

Fischer exact tests for comparing the haplotype and lineage distributions among the island populations were significant $(P<0.005)$ in both cases, indicating differentiation among island populations. Furthermore, an AMOVA test was performed to examine components of variance between the two groups of island populations, among islands within these two groups and within islands. The islands were grouped depending on the presence and frequency of each haplotype found: Majorca and Minorca (Gymnesic islands) where the haplotype A1 is exclusively present, and Ibiza and
Formentera (Pityusic islands) that share the presence of the haplotype M6. Results are shown in Table III. Thirty-five percent of the total variance is due to the differences between the two groups of islands, thus confirming the influence of the geographical localization in the haplotype distribution. Only $10 \%$ of the total variance is due to the differences within the Gymnesic and the Pityusic archipelagos, and suggests a certain level of homogeneity within these two groups. Fifty-four per cent of the variance depends on the differences within each island.

The maximum-likelihood tree obtained with the observed frequency of each haplotype (Fig. 3) also corroborates the grouping of the Gymnesic and the Pityusic islands. Honeybee populations from Ibiza and Formentera branch closer to the population from

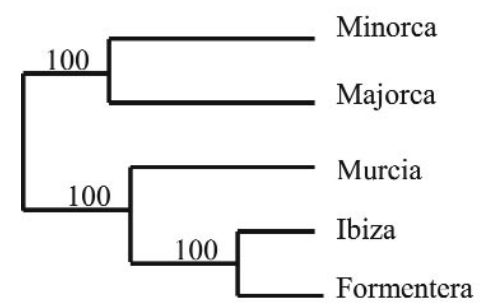

Figure 3. Maximum-likelihood tree (unrooted) of the honeybee populations from the Balearic islands based on the mitochondrial variation. Bootstrap values are noted as percentages and were computed over 2000 replications of the data sets. 
Murcia that was taken as representative of the continental A. m. iberica populations.

\section{DISCUSSION}

Molecular analyses of the mitochondrial DNA of A. mellifera populations from the Balearic islands of Majorca, Minorca, Ibiza and Formentera show that $75 \%$ of the studied colonies belong to the African evolutionary lineage of subspecies. This result is in agreement with previous data of honeybee populations from other Mediterranean islands as Sicily, Malta and some Greek islands (Garnery et al., 1993; Sheppard et al., 1997; Franck et al., 2000a). These data support the hypothesis pointed out by Ruttner (1988), and expanded by Sheppard et al. (1997) about the location of honeybee refugia in the Mediterranean area during the Pleistocene glaciation era, and a subsequent expanding period of these populations to the rest of Europe and the Mediterranean islands.

The results of Franck et al. (2000a) confirmed the presence of African haplotypes in two $A$. $m$. sicula populations that show the haplotypes A1, A2, A4 and A8. The A2 haplotype has also been found in Ibiza but not in the other three Balearic populations, in spite of the close geographical situation of these islands. On the other hand, the haplotype A1 was fixed (frequency $=1$ ) in populations from Majorca and detected at a high frequency $(84 \%)$ on Minorca. This haplotype has been described in populations from Morocco and is especially frequent in $A . m$. intermissa populations from south of the Atlas mountains and Guinea (Franck et al., 1998). It has also been found in southern Iberia (but in a low frequency) in A. m. iberica colonies with African haplotypes (Garnery et al., 1995; de la Rúa et al., 1999), in the Canary islands (de la Rúa et al., 1998, 2001a) with a variable frequency, and in Sicily (Franck et al., 2000a). The distribution of the haplotype A1 in the large islands supports a close link between the honeybee populations from Majorca and Minorca. These islands suffered several processes of connection and separation during historical times. The last time they were connected was around 25000 years ago (Compte, 1968) thus having the chance to homogenize the gene pool of their honeybee populations. The high frequency of this haplotype suggests a colonization event, such as described for other organisms located in the Balearic islands as Drosophila subobscura (Castro et al., 1999).

Haplotypes characteristic of west European honeybee populations have been found on Formentera and Ibiza (M6, 100\% and $52 \%$ respectively) and at a low frequency on Minorca (M8, 16\%). The homogeneous presence of the M6 haplotype in Formentera, a very small island with a few colonies, could reflect a recent bottleneck event. The M8 haplotype observed on Minorca has been previously detected at low frequencies in the southern part of France and also in the $A$. $m$. iberica populations with mellifera haplotypes from northern Iberia (Garnery et al., 1998a). These findings could reflect an anthropogenic influence in recent historical times, due to importations from Iberia that have been occurring during the last decades, as communicated to us by local beekeepers in Ibiza.

The haplotype distribution allows the clustering of the island honeybee populations in two groups: the large islands Majorca and Minorca (Gymnesic) and the small islands Ibiza and Formentera (Pityusic). This cluster agrees with the postulated separate history of both archipelagos, (Majorca and Minorca got separated from the Iberian mainland before Ibiza and Formentera and suffered several episodes of separation and union) which is also mirrored by other insect and plants groups (Palmer et al., 1999). Interestingly, only birds do not seem to reflect this paleogeographic trend.

The variability found in the Balearic islands is perhaps due to more than one 
factor, including historical processes (in a geological scale) and recent human influences. Similar results have been observed in populations of A. mellifera in the Canary islands, where many native populations characterized by a particular mitochondrial intergenic region have suffered a marked introgression caused by importation of foreign queens of the East European evolutionary lineage (de la Rúa et al., 1998, $2001 a, b)$. If queen replacement is maintained or increased during the next years in the Balearic islands, the gene pool of locally adapted populations could be severely disrupted. This process could cause the extinction of ecotypes adapted to the environmental conditions of these islands. Further research must be done for evaluating the factors that influence the genetic diversity of Balearic honeybee populations, and for establishing policies to preserve local populations with conservation interest.

\section{ACKNOWLEDGMENTS}

Special thanks are given to José A. Acosta for his help and advice during the sampling travel to Majorca and Minorca and to Dr. Bárbara Fernández for her help during the lab work. We are indebted to the beekeepers Jaume Martorell, Joan Massanet, Tomeu Gual, Gabriel Vicens, Baltasar Pons and Antonio Cerdá from Majorca, Sebastiá Pons, José Llufriú, Antoni Truyol and Miquel Truyol from Minorca, Francisco Clapés and José Suñer from Ibiza and Vicente Ribas and Pascual Mayans from Formentera, that contributed to this work with their honeybees and comments. Two anonymous referees and Dr. Stefan Fuchs (Editor) also contributed to improve the ms. This study has been supported by the DAAD-Acciones Integradas Hispano-Alemanas HA 1998-0043, and the projects RZ00-013 (Spanish National Institute of Agricultural Investigation, INIA) and EVK-2000-00628 (European 5th Framework).

Résumé - Caractérisation moléculaire et structure des populations d'abeilles domestiques des îles Baléares (Espagne). Les études moléculaires qui sont partiellement en accord avec les résultats d'études morphologiques et comportementales précédentes, ont défini quatre lignées évolutives de sous-espèces de l'abeille domestique Apis mellifera L. M (sous-espèces d'Europe occidentale), C (sous-espèces d'Europe orientale et du nord de la Méditerranée), A (sous-espèces africaines y compris les sous-espèces des îles de la Méditerranée telles que $A$. $m$. sicula de Sicile et $A$. $m$. ruttneri de Malte), et $\mathrm{O}$ (sous-espèces du Proche et du Moyen Orient). Ces études reposent sur la variation trouvée dans le génome mitochondrial d'A. mellifera (polymorphismes de longueur et des sites de restriction). Hall et Smith ont identifié des sites de restriction de diagnostic dans trois régions des mitochondries et Garnery et al. ont mis au point le test DraI basé sur le RFLP (polymorphisme de longueur des fragments de restriction) dans la région intergénique entre le tRNA ${ }^{\text {leu }}$ et COII. Cette région intergénique est composée de deux séquences dénommées $\mathrm{P}$ et $\mathrm{Q}$. Le type de séquence $\mathrm{P}$ et le nombre de répétition de $\mathrm{Q}$ varient d'une sous-espèce à l'autre et peuvent être utilisés pour identifier des colonies appartenant aux quatre lignées évolutives mentionnées ci-dessus.

Les îles Baléares sont situées en mer Méditerranée occidentale près de la côte orientale de l'Espagne réparties en deux groupes : Majorque et Minorque (archipel Gymnésique) et Ibiza et Formentera (archipel Pityusique). Nous émettons l'hypothèse qu'il peut y avoir des différences entre les populations d'abeilles des deux archipels. Ces différences refléteraient l'histoire distincte qu'ont eue les deux archipels en termes de colonisation durant les deux derniers millions d'années, y compris le moment où $A$. mellifera a probablement étendu son aire vers l'ouest à partir de la Méditerranée orientale.

Dans cette étude nous avons analysé la variation mitochondriale de 110 colonies d'abeilles présentes sur les îles Baléares (Fig. 1, Tab. I). Nous avons trouvé deux lignées évolutives et quatre haplotypes (Tabs. I et II) : les haplotypes africains A1 et A2, caractérisés par la présence de la séquence $\mathrm{P}_{0}$ et respectivement d'une ou deux 
unités Q, et les haplotypes d'Europe occidentale M6 et M8, qui possèdent également une ou deux unités Q mais ont la séquence $\mathrm{P}$ (Fig. 2). La fréquence et la distribution de ces haplotypes varient selon les îles (Fig. 1). Tous les échantillons de Majorque présentent l'haplotype A1 ; sur Minorque $84 \%$ des abeilles portent l'haplotype A1 mais nous avons également trouvé des abeilles qui portaient l'haplotype M8 d'Europe occidentale. Sur Ibiza $48 \%$ des colonies présentent l'haplotype africain A2 et $52 \%$ appartiennent à la lignée M (haplotype M6). Tous les échantillons de Formentera portent l'haplotype M6. L'analyse AMOVA de la variation haplotypique parmi les populations des îles Baléares et l'arbre de maximum de vraisemblance (Fig. 3) ont confirmé le rassemblement en deux groupes d'îles : MajorqueMinorque et Ibiza-Formentera. Ce résultat est en accord avec l'histoire différente des deux archipels. Pourtant les abeilles de Majorque et Minorque partagent la présence de l'haplotype A1, qui suggère une étroite relation entre les populations insulaires. Le fait que ces populations partagent l'ADNmt africain comme A. $m$. sicula en Sicile et A. $m$. ruttneri à Malte, confirment l'hypothèse de Ruttner et de Sheppard, pour lesquels les refuges des abeilles domestiques au cours de la glaciation pléistocène étaient situés dans la région méditerranéenne, puis une période d'expansion a suivi durant laquelle ces populations se sont répandues dans le reste de l'Europe et les îles méditerranéennes. Les caractéristiques haplotypiques des populations d'Europe occidentale ont été trouvées à Formentera et Ibiza et avec une moindre fréquence à Minorque, ce qui peut s'expliquer par l'importation d'Ibérie comme l'ont mentionné des apiculteurs locaux.

L'analyse des marqueurs mitochondriaux des population d'abeilles des Baléares fournit des preuves de l'influence des facteurs naturels et humains sur la biodiversité actuelle.

Apis mellifera / îles Baléares / biogéographie / ADNmt / génétique des populations
Zusammenfassung - Molekulare Charakterisierung und Populationsstruktur der Honigbienen von den Balearischen Inseln (Spanien). Durch molekulare Studien wurden in teilweiser Übereinstimmung mit früheren morphologischen und Verhaltensuntersuchungen vier evolutionäre Linien von Unterarten der Honigbiene Apis mellifera abgegrenzt, $M$ (Westeuropäische Unterarten) C (Osteuropäische und Nordmediterrane Unterarten) A (afrikanische Subspezies einschließlich mediterraner Inselrassen wie A. m. sicula von Sizilien and A. m. ruttneri von Malta) und O (Subspezies des nahen und mittleren Ostens). Diese Studien begründen sich aus der Variation des mitochondrialen Genoms von A. mellifera (Längen und Restriktionsortpolymorphismen). Hall und Smith (1991) fanden diagnostische Restriktionsschnittstellen in drei mitochondrialen Regionen und Garnery et. al. (1993) entwickelten den DraI test auf der Basis des RFLP der intergenischen Region zwischen tRNA $^{\text {leu }}$ und COII. Diese intergenische Region wird aus zwei Sequenzen, P und Q, zusammengesetzt, wobei die Anzahl der Q Wiederholungen sich zwischen den Subspezies unterscheidet und dazu genutzt werden kann, Völker den obengenannten evolutionären Linien zuzuordnen.

Die balearischen Inseln liegen im westlichen Mittelmeer nahe der spanischen Küste, sie teilen sich in zwei Gruppen auf: Mallorca und Minorca bilden die gymnesische Inselgruppe, Ibiza und Formentera die pityusische Inselgruppe. Wir untersuchten die Hypothese, dass sich die Populationen dieser beiden Inselgruppen unterscheiden. Solche Unterschiede würden die getrennte Geschichte beider Inselgruppen im Sinne der Besiedlungsgeschichte über die letzten 2 Millionen Jahre widerspiegeln. Dies schließt die Zeit ein, während der Apis mellifera mutmasslicherweise ihr Verbreitungsgebiet vom östlichen Mittelmeer in westlicher Richtung ausdehnte.

In der vorliegenden Studie untersuchten wir die mitochondriale Variation von 110 Bienenvölkern der Balearischen Inseln (Abb. 1 und Tab. I). Wir fanden zwei der 
evolutionären Linien und vier Haplotypen vertreten (Tab. I und II): die afrikanischen Haplotypen A1 and A2, charakterisiert durch die $\mathrm{P}_{0}$ Sequenz und eine beziehungsweise zwei Q Einheiten, und die Haplotypen M6 und M8 der westeuropäische Linie, ebenfalls mit ein oder zwei Q Einheiten, aber mit der P Sequenz (Abb. 2). Die Häufigkeit und Verteilung dieser haplotypen unterscheidet sich zwischen den Inseln (Abb. 1). Alle Proben von Mallorca zeigen den Haplotyp A1, auf Minorca hatten $84 \%$ der Bienen den Haplotyp A1, allerdings fanden wir auch Honigbienen mit dem westeuropäischen Haplotyp M8. Auf Ibiza zeigten $48 \%$ der Völker den afrikanischen Haplotyp A2, und $52 \%$ gehörten der M Linie an (Haplotyp M6). Alle Proben von Formentera zeigten den Haplotyp M6. Die AMOVA Analyse der Haplotypvariation zwischen den balearischen Honigbienenpopulationen (Tab. III) und der Maximum-Likelihood Tree (Abb. 3) bestätigten die zwei Inselgruppen MajorcaMinorca und Ibiza-Formentera. Dies Ergebnis steht mit der getrennten Geschichte der beiden Inselgruppen im Einklang. In der Tat teilen die Bienen von Mallorca und Minorca die Anwesenheit des Haplotyps A1, was eine enge Beziehung zwischen den Inseln nahe legt. Die Tatsache, dass diese Populationen ähnlich wie $A$. $m$. sicula in Sizilien and $A$. $m$. ruttneri in Malta afrikanische mtDNA enthalten, unterstützt Ruttner's und Sheppard's Hypothese über mediterrane eiszeitliche Refugien und eine darauffolgende Expansion dieser Populationen nach Europa und über die Mittelmeerinseln. Für Westeuropa charakteristische Bienenpopulationen wurden auf Formentera und Ibiza und zu ganz geringen Anteilen auf Minorca gefunden. Diese sind entsprechend von Berichten örtlicher Bienenhalter möglicherweise auf Importe von Spanien zurückzuführen. Die Analyse mitochondrialer Marker der balearischen Honigbienenpopulation belegt hiermit sowohl natürliche als auch vom Menschen ausgehende Einflüssse auf die derzeitige Biodiversität.

Apis mellifera / Balearische Inseln / mtDNA / Biogeographie

\section{REFERENCES}

Arias M.C., Sheppard W.S. (1996) Molecular phylogenetics of honey bee subspecies (Apis mellifera L.) inferred from mitochondrial DNA sequences, Mol. Phylogenet. Evol. 5, 557-566.

Castro J.A., Ramon M., Picornell A., Moya A. (1999) The genetic structure of Drosophila suboscura populations from the islands of Majorca and Minorca (Balearic islands, Spain) based on allozymes and mitochondrial DNA, Heredity 83, 271-279.

Colom G. (1964) El medio y la vida en las Baleares, Gráfica Miramar, Palma de Mallorca.

Compte A. (1968) La fauna de Menorca y su origen, Revista de Menorca, Mahón.

Cornuet J.-M., Garnery L. (1991) Mitochondrial DNA variability in honeybees and its phylogenetic implications, Apidologie 22, 627-642.

Crozier Y.C., Koulianos S., Crozier R.H. (1991) An improved test for Africanized honeybee mitochondrial DNA, Experientia 47, 968-969.

Cuerda J. (1975) Los tiempos cuaternarios en Baleares, Institut d'Estudis Baleàrics, Palma de Mallorca.

de la Rúa P., Galián J., Serrano J. (1998) Mitochondrial variability of honeybee populations from the Canary islands, Mol. Ecol. 7, 1543-1547.

de la Rúa P., Galián J., Serrano J. (1999) Variabilidad mitocondrial en poblaciones de abejas de la mie del Sureste Peninsular, Invest. Agric. Prod. Sanid. Anim. 14, 24-30.

de la Rúa P., Galián J., Serrano J., Moritz R.F.A. (2001a) Genetic structure and distinctness of Apis mellifera L. populations from the Canary islands, Mol. Ecol. 10, 1733-1742.

de la Rúa P., Galián J., Serrano J. (2001b) Biodiversity of Apis mellifera populations from Tenerife (Canary islands) and hybridisation with East European races, Biodiv. Conserv. (in press).

Estoup A., Garnery M., Solignac M., Cornuet J.-M. (1995) Microsatellite variation in honeybee (Apis mellifera L.) populations: hierarchical genetic structure and test of the infinite allele and stepwise mutation models, Genetics 140, 679-695.

Felsenstein J. (1993) PHYLIP, phylogeny inference package, Version 3.5, University of Washington, Seattle.

Franck P., Garnery L., Solignac M., Cornuet J.-M. (1998) The origin of west European subspecies of honeybees (Apis mellifera): new insights from microsatellite and mitochondrial data, Evolution 52, 1119-1134.

Franck P., Garnery L., Celebrano G., Solignac M., Cornuet J.-M. (2000a) Hybrid origin of honeybees from Italy (Apis mellifera ligustica) and Sicily (A. m. sicula), Mol. Ecol. 9, 907-921.

Franck P., Garnery L., Solignac M., Cornuet J.-M. (2000b) Molecular confirmation of a Middle East lineage in Apis mellifera, Apidologie 31, 167-180. 
Garnery L., Cornuet J.-M., Solignac M. (1992) Evolutionary history of the honey bee Apis mellifera inferred from mitochondrial DNA analysis, Mol. Ecol. 1, 145-154.

Garnery L., Solignac M., Celebrano G., Cornuet J.-M. (1993) A simple test using restricted PCR-amplified mitochondrial DNA to study the genetic structure of Apis mellifera L., Experientia 49, 1016-1021.

Garnery L., Mosshine E.H., Cornuet J.-M. (1995) Mitochondrial DNA variation in Moroccan and Spanish honey bee populations, Mol. Ecol. 4, 465-471.

Garnery L., Franck P., Baudry E., Vautrin D., Cornuet J.-M., Solignac M. (1998a) Genetic biodiversity of the west European honeybee (Apis mellifera mellifera and A. m. iberica). I. Mitochondrial DNA, Genet. Sel. Evol. 30, 31-47.

Garnery L., Franck P., Baudry E., Vautrin D., Cornuet J.-M., Solignac M. (1998b) Genetic biodiversity of the west European honeybee (Apis mellifera mellifera and A. m. iberica). II. Microsatellite DNA, Genet. Sel. Evol. 30, 49-74.

Hall H.G., Smith D.R. (1991) Distinguishing African and European honey bee matrilines using amplified mitochondrial DNA, Proc. Natl. Acad. Sci. USA 88, 4548-4552.

Hedges S.B. (1992) The number of replications needed for accurate estimation of the bootstrap $P$ value in phylogenetic studies, Mol. Biol. Evol. 9, 366-369.

Palmer M., Pons G.X., Cambefort Y., Alcover J.A. (1999) Historical processes and environmental factors as determinants of inter-island differences in endemic faunas: The case of the Balearic islands, J. Biogeogr. 26, 813-824.

Palmer M.R., Smith D.R., Kaftanoglu O. (2000) Turkish honeybees: genetic variation and evidence for a fourth lineage mtDNA, J. Hered. 91, 42-46.
Raymond M., Rousset F. (1995) GENEPOP (version 1.2): population genetics software for exact test and ecumenism, J. Hered. 86, 248-250.

Ruttner F. (1988) Biogeography and Taxonomy of Honeybees, Springer Verlag, Berlin.

Schneider S., Kueffer J.-M., Roessli D., Excofier L., Arlequin: a software for population genetic data analysis, Version 1.1. (1997) Genetics and Biometry Laboratory, Deparment of Anthropology, University of Geneva, Switzerland.

Sheppard W.S., Rinderer T.E., Meixner M.D., Yoo H.R., Stelzer J.A., Schiff N.M., Kamel S.M., Krell R. (1996) HinfI variation in mitochondrial DNA of old world honey bee subspecies, J. Hered. 87, 35-40.

Sheppard W.S., Arias M.C., Grech A., Meixner M.D (1997) Apis mellifera ruttneri, a new honey bee subspecies from Malta, Apidologie 28, 287-293.

Sheppard W.S., Smith D.R. (2000) Identification of African-derived bees in the Americas: a survey of methods, Ann. Entomol. Soc. Am. 93 159-176.

Smith D.R., Palopoli M.F., Taylor B.R., Garnery L., Cornuet J.-M., Solignac M., Brown M. (1991) Geographical overlap of two mitochondrial genomes in Spanish honeybees (Apis mellifera iberica), J. Hered. 82, 96-100.

Smith D.R., Slaymaker A., Palmer M., Kaftanoglu O. (1997) Turkish honey bees belong to the east Mediterranean lineage, Apidologie 28, 269-274.

Walsh P.S., Metzqer D.A., Higuchi R. (1991) Chelex 100 as a medium for simple extraction of DNA for PCR-based typing from forensic material, Biotechniques $10,506-512$. 